\title{
Factors associated with the financial performance of spring-calving, pasture-based dairy farms
}

\author{
G. Ramsbottom, ${ }^{\star}$ B. Horan, $†$ D. P. Berry, $†$ and J. R. Roche $\ddagger^{1}$ \\ *Teagasc, Oak Park, Carlow, Ireland \\ †Animal and Grassland Research and Innovation Centre, Teagasc, Moorepark, Co. Cork, Ireland \\ ‡DairyNZ, Private Bag 3221, Hamilton 3210, New Zealand
}

\section{ABSTRACT}

As land becomes a limiting resource for pasture-based dairy farming, the inclusion of purchased supplementary feeds to increase milk production per cow (through greater dry matter intake) and per hectare (through increased stocking rate) is often proposed as a strategy to increase profitability. Although a plausible proposition, virtually no analysis has been done on the effect of such intensification on the profitability of commercial pasture-based dairy farm businesses. The objective of this study was to characterize the average physical and financial performance of dairy systems differing in the proportion of the cow's diet coming from grazed pasture versus purchased supplementary feeds over $4 \mathrm{yr}$, while accounting for any interaction with geographic region. Physical, genetic, and financial performance data from 1,561 seasonal-calving, pasture-based dairy farms in Ireland were available between the years 2008 and 2011; data from some herds were available for more than $1 \mathrm{yr}$ of the 4-yr study period, providing data from 2,759 dairy farm-years. The data set was divided into geographic regions, based on latitude, rainfall, and soil characteristics that relate to drainage; these factors influence the length of the pasture growth season and the timing of turnout to pasture in spring and rehousing in autumn. Farms were also categorized by the quantity of feed purchased; farms in which cows received $<10,11-20,21-30$, or $>30 \%$ of their annual feed requirements from purchased feed were considered to be categories representative of increasing levels of system intensification. Geographic region was associated with differences in grazing days, pasture harvested per hectare, milk production per cow and per hectare, and farm profitability. Farms in regions with longer grazing seasons harvested a greater amount of pasture [an ad-

Received June 24, 2014.

Accepted January 23, 2015.

${ }^{1}$ Corresponding author: john.roche@dairynz.co.nz ditional $19 \mathrm{~kg}$ of dry matter (DM)/ha per grazing day per hectare], and greater pasture harvested was associated with increased milk component yield per hectare (58.4 kg of fat and $51.4 \mathrm{~kg}$ of protein more per tonne of DM pasture harvested/ha) and net profit per hectare (€268/ha more per tonne of DM harvested). Milk yield and yield of milk components per cow and per hectare increased linearly with increased use of purchased feed (additional $30.6 \mathrm{~kg}$ of milk fat and $26.7 \mathrm{~kg}$ of milk protein per tonne of DM purchased feed per hectare), but, on average, pasture harvested/hectare and net profit/ hectare declined $(-0.60 \mathrm{t}$ of $\mathrm{DM} / \mathrm{ha}$ and $-€ 78.2 /$ ha, respectively) with every tonne of DM supplementary feed purchased per hectare. The results indicate an effect of purchased feeds not usually accounted for in marginal economic analyses (e.g., milk to feed price ratio): the decline in pasture harvested/hectare, with the costs of producing the unutilized pasture in addition to the cost of feed resulting in a lower profit. In conclusion, greater milk component yields per cow were associated with increased profit per hectare, and a greater use of purchased feeds was associated with an increase in the yield of milk components. However, on average, increasing yield of milk components through the supply of purchased feeds to pasture-based cows was associated with a decline in pasture harvested per hectare and profitability. The decline in pasture harvested per hectare with increased use of purchased supplements per cow is probably the primary reason for the low milk production response and the failure to capitalize on the potential benefits of purchased supplements, with the associated costs of growing the unutilized pasture, in conjunction with increased nonfeed variable and fixed costs outweighing the increased milk production and revenue from supplementation. Farmers considering intensification through use of purchased supplements to increase the stock-carrying capacity of the farm (i.e., stocking rate) must ensure that they focus on management of pasture and total cost control to capture the potential benefits of supplementary feed use.

Key words: dairy, grassland, farm systems, milk production, economics 


\section{INTRODUCTION}

There has been renewed interest in grazing production systems internationally because of milk price volatility and perceived animal welfare advantages (Dillon et al., 2005; Macdonald et al., 2008). Efficient grazing dairy systems are designed to optimize the use of grazed grass while maximizing lactation length and individual cow DMI. In the context of predominantly pasture-based milk production, the farming system most suited to this pasture growth pattern involves a compact calving period in spring, just before the flush of pasture growth, attempting, as much as possible, to match the seasonal supply of pasture and the herd intake demand (Dillon et al., 1995; Macdonald et al., 2008).

Because of the low cow DMI under grazing compared with cows consuming TMR (Kolver and Muller, 1998), grazing dairy cows tend to have low milk production/ cow compared with housed cows; however, they also tend to have relatively low production costs per kilogram of milk and per kilogram of milk fat and protein (Dillon et al. 1995; Macdonald et al., 2011). Furthermore, although milk production/cow is low, milk production/hectare can be high (Macdonald et al., 2008; McCarthy et al., 2011). Nonetheless, the low milk production per cow is often seen as a limitation that can be improved upon through improved genetics (Ramsbottom et al., 2012), reduced stocking rate (Macdonald et al., 2008; McCarthy et al., 2011), or the provision of additional feed as a supplement to pasture (Kennedy et al., 2002; Horan et al., 2004; Roche et al., 2006). There are well-defined response curves to these management changes and, in theory, it is possible to increase milk production/cow through changes in these variables and improve productivity and profitability. For the most part, however, these response curves have been derived from data collated in controlled research environments, and very few studies have been conducted on commercial farms that describe the change in productivity and profitability that result from changes to these management variables.

The objective of this study was to utilize a database of farm physical and financial measurements to identify the main factors associated with farm profitability in commercial dairy herds and to determine the expected change in profitability with changes in these management variables.

\section{MATERIALS AND METHODS}

\section{The Seasonal-Calving Grazing System}

The optimum management protocol for seasonalcalving grazing systems was described in detail by
Macdonald and Penno (1998) and Macdonald et al. (2008). Briefly, management protocols aim to have the cow harvest as much pasture as possible (Dillon et al., 1995). Mechanical harvesting of silage is practiced when pasture growth exceeds herd demand, and cows are supplemented with concentrate feeds and conserved forages when pasture growth is less than cow requirements. In the Irish dairy system, average pasture consumed/hectare is estimated to be $7.3 \mathrm{t}$ of $\mathrm{DM} / \mathrm{ha}$ annually, with cows also receiving $875 \mathrm{~kg}$ of concentrates/ cow (Teagasc, 2012)

In temperate pasture systems, minimal pasture growth occurs during winter and early spring, and the peak of pasture growth occurs in mid-spring (Roche et al., 2009). As a result, cows are managed to minimize the requirements for fresh pasture during winter, through the provision of conserved forages, with or without housing, during the winter months, or are moved to an alternative property for feeding before calving, before being "turned out" to graze fresh pasture between early spring and early winter. Compact seasonal calving and breeding protocols ensure that the maximum numbers of cows are in peak lactation to coincide with peak pasture growth; the current median calving date in Ireland is March 14 (Teagasc, 2012). Producers apply "maintenance" dressings of phosphorus and potassium fertilizers and nitrogen at approximately $150 \mathrm{~kg}$ of N/ ha throughout the season to stimulate greater pasture growth for grazing and silage (Teagasc, 2012).

\section{Farm Physical Data}

Data used in the analysis were obtained from the Irish national dairy farm database (Profit Monitor, Teagasc, Ireland); the database contains farm physical and financial data for approximately 3,000 individual dairy farmer users. In the present study, farm physical and financial performance data were extracted for 1,561 spring-calving dairy farms (representing 2,759 farm-years) with $>20$ cows for the years 2008 to 2011 , inclusive. All herds had information on physical and financial performance.

Monthly numbers of cows, replacement heifers, and nondairy stock were averaged across each calendar year to determine average livestock units for each of the 3 respective stock categories. One livestock unit $(\mathbf{L U})$ is a bovine of over 2 yr of age: a 1- to 2-yr-old and a 0 - to 1-yr-old bovine are the equivalent of 0.7 and 0.3 LU, respectively. Farm stocking rate was calculated by dividing the hectares of forage area (pasture and forage crop area combined) utilized by the total LU on the farm.

Total milk sold by volume was divided by average dairy cow LU present on the farm to calculate aver- 
age milk yield per cow. Average annual milk fat and protein contents were obtained from the milk processor and used to calculate yields of milk fat and protein. Data on the number of cows calving each week of the year, as well as herd-average lactation length data, were obtained from the Irish Cattle Breeding Federation database.

Release to pasture following the winter housing period is often phased; lactating dairy cows, in particular, are often provided access to pasture during daytime and are housed and fed silage during the night before full-time access to pasture is granted. Part-time and full-time release to pasture and full-time housing dates were recorded. Each part-time grazing day was assumed to be the equivalent of half of one full-time grazing day. Grazing days per cow were calculated by combining grazing data and calving data patterns for individual herds. The number of grazing days per cow for cows calving before the date of first release to pasture were calculated using the assumption that they were released to pasture from the date of first release. Grazing days for cows calving after the date of first release to grazing were calculated from the date of calving. Grazing days per cow were averaged for all cows in the herd. Grazing days per hectare were obtained by multiplying stocking rate and average grazing days per cow. For example, 40 cows, on a farm stocked at $2.0 \mathrm{LU} /$ ha, were released to pasture part-time on February 20, fully released to pasture $8 \mathrm{~d}$ later, and housed on November 20. Grazing days per cow is calculated by dividing the number of part-time grazing days by 2 and adding the answer to the number of full time grazing days; that is, 269 full-time grazing days per cow or 538 grazing days per hectare.

The quantity of dairy cow feed and purchased forage that was consumed per cow was calculated by dividing the purchased dairy cow feed and forage cost per cow by the cost per tonne of the respective feed. Dry matter required per average cow in the herd was calculated from their milk production and an estimate of maintenance, activity, and pregnancy energy requirements (Holmes, 2007). Pasture harvested per cow (i.e., grazed and conserved pasture) was calculated by deducting feed and purchased forage inputs from total cow requirement for milk production. Pasture harvested per hectare was calculated by multiplying pasture harvested per cow by the stocking rate.

\section{Farm Financial Data}

All financial data are expressed in euro $(€)$ unless otherwise stated. Market values were used where animals were purchased or sold off farm. Where transfers from the dairy herd to heifer or drystock enterprises took place, standard economic values per animal were used across all farms and years. Dairy cows were valued at $€ 700$ each (or approximately 2,191 L of milk per head); newborn replacement and beef calves transferred from the dairy enterprise were valued at $€ 300$ and $€ 150$, respectively (or approximately 939 and $469 \mathrm{~L}$ of milk per head respectively). Similarly, the standard cost of $€ 1,000$ per head (or approximately 3,130 L of milk per head) was used where freshening replacements were transferred to the dairy enterprise.

Farm gross revenue was calculated by combining milk sales receipts, stock sales, and the standard value of calf transfers to beef and heifer enterprises. The cost of purchased freshening heifers and cows or the standard value of freshening heifers transferred from the farm's replacement heifer enterprise were deducted, and an adjustment made for stock inventory change, where applicable. This new variable will be referred to as "gross revenue output."

Variable costs recorded in Profit Monitor included feed and fertilizer; breeding and veterinary costs; and farm contractor costs; as well as other variable costs, including milk recording, parlor expenses, and bedding costs. Dairy cow feed and parlor expenses were allocated directly to the dairy enterprise. Most of the other variable costs were apportioned in the Profit Monitor system on a percentage LU basis. For example, if the dairy enterprise accounted for $60 \%$ of the farm's total $\mathrm{LU}$, then $60 \%$ of the remaining variable costs were allocated to the dairy enterprise.

Fixed costs recorded include machinery running and lease costs, hired labor, repairs and maintenance, depreciation, electricity, phone and transportation expenses, as well as the costs of leasing land and milk quota. Dairy cow fixed costs were allocated in proportion to the percentage of the farm's gross revenue output attributed to the dairy enterprise.

Net profit was calculated as the profit remaining after all variable and fixed costs were deducted from the gross revenue output. Net profit/liter of milk produced was calculated by dividing the total net profit of the dairy enterprise by the total volume of milk produced on the farm. Net profit per cow was calculated by multiplying net profit/liter by the average milk sold/cow. Net profit/hectare was calculated by multiplying net profit/cow by the average farm stocking rate. Variable costs, fixed costs, and gross revenue output per liter, per cow, and per hectare were calculated using a similar approach.

\section{Geographical Classification}

Farms were divided according to 5 geographical regions of origin, which differ in their seasonal production 
of pasture and their rainfall: (1) farms in county Cork (Cork region) are characterized by free draining soils, adequate rainfall, and a long pasture-growing season (i.e., $728 \mathrm{~mm}$ of rain and $33 \mathrm{~d}$ with ground frost at Roche's Point weather station; Met Eireann, 2014); (2) farms from counties Dublin, Kildare, Laois, Longford, Louth, Meath, Offaly, North Tipperary, Westmeath, and Wicklow (Midlands region), which have similar rainfall, but cooler winters and, as a result, a shorter growing season (i.e., 814 and $932 \mathrm{~mm}$ of rain and 100 and $97 \mathrm{~d}$ with ground frost at Birr and Mullingar weather stations, respectively; Met Eireann, 2014); (3) farms from counties Cavan, Clare, Donegal, Galway, Leitrim, Mayo, Monaghan, Roscommon, and Sligo (Northwest region), which have high rainfall and a short pasture growth season (i.e., 1,136 and $928 \mathrm{~mm}$ of rain and 97 and $99 \mathrm{~d}$ with ground frost at Claremorris and Clones weather stations, respectively; Met Eireann, 2014); (4) farms from counties Carlow, Kilkenny, South Tipperary, Waterford, and Wexford (Southeast region), which have low rainfall characterized by summer moisture stress-related reduction in pasture growth (i.e., 847 and $860 \mathrm{~mm}$ of rain and 43 and $114 \mathrm{~d}$ with ground frost at Kilkenny and Rosslare weather stations, respectively; Met Eireann, 2014); and (5) farms from counties Kerry and Limerick (Southwest region), which are typified by heavy, less free draining soils, high rainfall, and long pasture-growing seasons (i.e., 1,430 $\mathrm{mm}$ rain and $39 \mathrm{~d}$ with ground frost; Met Eireann, 2014).

\section{Production System Classification}

Hedley et al. (2006) defined 5 levels of system intensification in New Zealand pasture-based systems on the basis of the proportion of the total diet of the cow that was provided by supplementary feed. Using the same rationale, data presented here were categorized into 4 farm systems on the basis of amount of feed purchased/cow: systems $1,2,3$, and 4 refer to systems in which $<10 \%, 11-20 \%, 21-30 \%$, or $>30 \%$ of total annual feed requirements are purchased, respectively. Because practically no dairy farms in Ireland practice the equivalent of the Hedley et al. (2006) system 1, Hedley et al. (2006) systems 1 and 2 were merged in the current study as system 1 . Hedley et al. (2006) systems 3,4 , and 5 are equivalent to systems 2,3 , and 4 in this study.

To account for the multiple types of feeds used with increased system intensification (i.e., concentrates and forages), it was assumed that purchased forage supplements contained 10.5 MJ of ME $/ \mathrm{kg}$ of $\mathrm{DM}$ and purchased concentrates contained $12 \mathrm{MJ}$ of $\mathrm{ME} / \mathrm{kg}$ of DM. A concentrate-equivalent variable was thus defined by combining all of the ME in purchased feeds and dividing by 12 (i.e., the assumed approximate ME in the concentrate). Response to feed supplementation is, therefore, presented relative to this concentrateequivalent variable.

\section{Genetic Data}

Average genetic information for each herd for the individual traits included in the economic breeding index (EBI), as well as genetic merit for overall cow conformation, was extracted from the Irish Cattle Breeding Federation database for the lactating dairy cows present on the farm in each year. Economic values in 2012 were used to calculate the herd-average EBI as well as the production and fertility sub-indices of the EBI. The EBI and its sub-indices are described in detail by Berry et al. (2007); EBI is expressed as expected profit per lactation of the progeny of the animal in question, and the genetic merit values of the component traits are, therefore, expressed as predicted transmitting abilities (PTA). The index is composed of 6 sub-indices: production, fertility, calving performance, beef performance, maintenance, and health.

Following the merging of genetic and Profit Monitor data (i.e., milk production and financial performance), 1,561 herds representing 2,759 herd-years remained for inclusion in the analysis.

\section{Data Analysis}

A series of analyses was undertaken in SAS (SAS Institute, 2005) to characterize the physical, genetic, and financial data for each geographical region and system of production. The analyses were undertaken using mixed model equations in PROC MIXED (SAS Institute, 2005); each model included the fixed effects of year (2008 to 2011), geographic region, and system of production, as well as the interaction between system and year; herd was included in all models as a repeated effect.

A second series of analyses was undertaken using mixed models in PROC MIXED (SAS Institute, 2005) to determine the factors associated with farm physical and financial performance. The fixed effects of interest considered in the model included farm stocking rate, milk yield/cow, median herd calving date, date of turnout to pasture and date of rehousing, milk fat and protein contents, and pasture harvested/hectare. Fixed effects tested for inclusion in the model were year (2008 to 2011), system of production, and geographical region. Noncontributing explanatory variables were excluded from the model by a process of backward elimination. The proportion of variation explained by the mixed model was calculated from the square of the 
correlation between the value of dependent variable and the predicted value from the mixed model.

\section{RESULTS}

\section{Geographic Region}

Summary statistics for a range of performance parameters for different geographical regions are summarized in Table 1. Herd size, stocking rate, turnout date to pasture in spring and rehousing date in autumn, and grazing season length all varied $(P<0.001)$ by geographical region. The Cork region had the highest stocking rate and, together with the Midlands and Southeast regions, the largest herd size. The Cork and Southeast regions had earlier turnout of animals to pasture and, in common with the Midlands region, later rehousing. In comparison, the Northwest region had the smallest herds and, along with the Southwest region, the lowest stocking rate.

Factors influencing days spent grazing and pasture harvested/hectare $(P<0.001)$ and the amount of feed purchased $(P<0.001)$ differed across geographical regions. Pasture harvested/hectare was greatest for Cork. Grazing days/hectare were greater for Cork, Midlands, and Southeast regions and least for the Southwest region. Milk production (volumes and yields of fat and protein) per cow and per hectare was greatest $(P<$ 0.001) in Cork, least in the Northwest, and intermediate in the other regions, due in part to a regional effect on lactation length. Herd-average EBI (i.e., national genetic merit index) was greatest $(P<0.001)$ in the Midlands and Southeast and least in the Northwest, whereas Cork and the Southwest were intermediate. The milk production potential (milk sub-index value and PTA for milk yield) of dairy cows was greatest in Cork, whereas dairy cattle in the Midlands had the greatest genetic potential for fertility.

Summary statistics for a range of financial characteristics across the reported geographical regions are summarized in Table 2 and reflect an association between geographic region and most of the financial variables recorded. Milk price and gross revenue per liter, per cow, and per hectare were greatest $(P<0.001)$ in Cork and similar in the other regions. Variable milk production costs per liter were greatest in the Southwest region, intermediate in the Northwest, and lowest in the other regions. The Northwest region had the lowest variable costs per cow and per hectare; the greatest variable costs per hectare were in the Cork region. Total fixed

Table 1. Biological characteristics in seasonal spring-calving, pasture-based dairy systems in different geographical regions ${ }^{1}$

\begin{tabular}{|c|c|c|c|c|c|c|c|}
\hline Item & Cork & Midlands & Northwest & Southeast & Southwest & $\mathrm{SE}$ & $P$-value \\
\hline No. of farms & 837 & 519 & 311 & 743 & 349 & & \\
\hline Herd size, no. of cows & $94^{\mathrm{a}}$ & $92^{\mathrm{a}}$ & $74^{\mathrm{b}}$ & $91^{\mathrm{a}}$ & $81^{\mathrm{c}}$ & 2.4 & 0.001 \\
\hline Stocking rate, $\mathrm{LU}^{2} /$ ha & $2.20^{\mathrm{a}}$ & $2.12^{\mathrm{b}}$ & $1.93^{\mathrm{c}}$ & $2.11^{\mathrm{b}}$ & $1.99^{\mathrm{c}}$ & 0.020 & 0.001 \\
\hline Median calving date, day of year & $57^{\mathrm{a}}$ & $62^{\mathrm{b}}$ & $67^{\mathrm{c}}$ & $55^{\mathrm{d}}$ & $63^{\mathrm{b}}$ & 0.7 & 0.001 \\
\hline Full time turnout, day of year & $59^{\mathrm{a}}$ & $63^{\mathrm{b}}$ & $70^{\mathrm{c}}$ & $59^{\mathrm{a}}$ & $66^{\mathrm{d}}$ & 1.2 & 0.001 \\
\hline Housing date, day of year & $321^{\mathrm{a}}$ & $321^{\mathrm{a}}$ & $314^{\mathrm{b}}$ & $322^{\mathrm{a}}$ & $317^{\mathrm{c}}$ & 0.81 & 0.001 \\
\hline Grazing days, no./ha & $577^{\mathrm{a}}$ & $578^{\mathrm{a}}$ & $540^{\mathrm{b}}$ & $558^{\mathrm{ab}}$ & $525^{\mathrm{b}}$ & 12.4 & 0.01 \\
\hline Pasture harvested, $\mathrm{t}$ of $\mathrm{DM} / \mathrm{ha}$ & $8.4^{\mathrm{a}}$ & $7.9^{\mathrm{b}}$ & $7.0^{\mathrm{c}}$ & $8.0^{\mathrm{b}}$ & $7.4^{\mathrm{d}}$ & 0.083 & 0.001 \\
\hline Purchased forage, $\mathrm{t}$ of $\mathrm{DM} / \mathrm{ha}$ & $0.36^{\mathrm{a}}$ & $0.32^{\mathrm{b}}$ & $0.28^{\mathrm{c}}$ & $0.32^{\mathrm{b}}$ & $0.28^{\mathrm{c}}$ & 0.015 & 0.001 \\
\hline Purchased concentrate, $\mathrm{t}$ of $\mathrm{DM} / \mathrm{ha}$ & $1.79^{\mathrm{a}}$ & $1.72^{\mathrm{b}}$ & $1.65^{\mathrm{c}}$ & $1.70^{\mathrm{bc}}$ & $1.71^{\mathrm{bc}}$ & 0.022 & 0.001 \\
\hline Purchased concentrate, $\mathrm{t}$ of $\mathrm{DM} /$ cow & $0.83^{\mathrm{a}}$ & $0.81^{\mathrm{ac}}$ & $0.85^{\mathrm{b}}$ & $0.81^{\mathrm{c}}$ & $0.85^{\mathrm{b}}$ & 0.008 & 0.001 \\
\hline Purchased feed, \% of total DM & $20.2^{\mathrm{ad}}$ & $20.0^{\mathrm{ac}}$ & $20.7^{\mathrm{b}}$ & $19.8^{\mathrm{c}}$ & $20.5^{\mathrm{bd}}$ & 0.17 & 0.001 \\
\hline \multicolumn{8}{|l|}{ Milk production } \\
\hline Lactation length, d (DIM) & $282^{\mathrm{a}}$ & $279^{\text {ad }}$ & $271^{\mathrm{b}}$ & $274^{\mathrm{bc}}$ & $277^{\mathrm{cd}}$ & 1.5 & 0.001 \\
\hline Milk yield, L/cow & $5,236^{\mathrm{a}}$ & $5,075^{\mathrm{b}}$ & $4,925^{\mathrm{c}}$ & $5,169^{\mathrm{d}}$ & $5,121^{\text {bd }}$ & 31.1 & 0.001 \\
\hline Milk yield, L/ha & $11,451^{\mathrm{a}}$ & $10,715^{\mathrm{b}}$ & $9,466^{\mathrm{c}}$ & $10,914^{\mathrm{b}}$ & $10,217^{\mathrm{d}}$ & 118.5 & 0.001 \\
\hline Fat yield, $\mathrm{kg} / \mathrm{cow}$ & $214^{\mathrm{a}}$ & $206^{\mathrm{b}}$ & $199^{\mathrm{c}}$ & $209^{\mathrm{b}}$ & $206^{\mathrm{b}}$ & 1.1 & 0.001 \\
\hline Fat yield, kg/ha & $467^{\mathrm{a}}$ & $436^{\mathrm{b}}$ & $383^{\mathrm{c}}$ & $441^{\mathrm{b}}$ & $411^{\mathrm{d}}$ & 5.0 & 0.001 \\
\hline Protein yield, $\mathrm{kg} / \mathrm{cow}$ & $186^{\mathrm{a}}$ & $178^{\mathrm{b}}$ & $172^{\mathrm{c}}$ & $183^{\mathrm{d}}$ & $180^{\mathrm{bd}}$ & 1.1 & 0.001 \\
\hline Protein yield, kg/ha & $406^{\mathrm{a}}$ & $376^{\mathrm{b}}$ & $331^{\mathrm{c}}$ & $386^{\mathrm{b}}$ & $360^{\mathrm{d}}$ & 4.3 & 0.001 \\
\hline \multicolumn{8}{|l|}{ Genetic merit } \\
\hline Herd EBI, ${ }^{3} €$ & $73^{\mathrm{a}}$ & $76^{\mathrm{b}}$ & $70^{\mathrm{c}}$ & $76^{\mathrm{b}}$ & $74^{\mathrm{ab}}$ & 0.9 & 0.001 \\
\hline Milk subindex, € & $32^{\mathrm{a}}$ & $20^{\mathrm{b}}$ & $23^{\mathrm{c}}$ & $22^{\mathrm{c}}$ & $28^{\mathrm{d}}$ & 0.7 & 0.001 \\
\hline Fertility subindex, € & $35^{\mathrm{a}}$ & $49^{\mathrm{b}}$ & $41^{c}$ & $47^{\mathrm{d}}$ & $40^{\mathrm{c}}$ & 0.9 & 0.001 \\
\hline PTA milk, $\mathrm{kg}$ & $95^{\mathrm{a}}$ & $34^{\mathrm{b}}$ & $53^{\mathrm{c}}$ & $36^{\mathrm{b}}$ & $70^{\mathrm{d}}$ & 3.7 & 0.001 \\
\hline
\end{tabular}

${ }^{\mathrm{a}-\mathrm{d}}$ Means with different superscripts differ significantly.

${ }^{1}$ Midlands = counties Kildare, Laois, Longford, Louth, Meath, Offaly, North Tipperary, Westmeath; Northwest = counties Cavan, Clare, Donegal, Galway, Leitrim, Mayo, Roscommon, Sligo; Southeast = counties Carlow, Kilkenny, South Tipperary, Waterford, Wexford; Southwest $=$ counties Kerry and Limerick.

${ }^{2}$ Livestock units.

${ }^{3}$ Economic breeding index. 
Table 2. Least squares means for financial performance in seasonal spring-calving, pasture-based dairy systems in geographical regions ${ }^{1}$

\begin{tabular}{|c|c|c|c|c|c|c|c|}
\hline Item & Cork & Midlands & Northwest & Southeast & Southwest & SE & $P$-value \\
\hline Milk price, $\mathrm{c} / \mathrm{L}$ & $31.7^{\mathrm{a}}$ & $30.6^{\mathrm{b}, \mathrm{c}}$ & $30.5^{\mathrm{b}}$ & $30.9^{c}$ & $30.8^{\mathrm{c}}$ & 0.07 & 0.001 \\
\hline \multicolumn{8}{|l|}{ Gross revenue } \\
\hline $\mathrm{c} / \mathrm{L}$ & $32.0^{\mathrm{a}}$ & $31.0^{\mathrm{b}}$ & $30.9^{\mathrm{b}}$ & $31.1^{\mathrm{b}}$ & $31.0^{\mathrm{b}}$ & 0.12 & 0.001 \\
\hline$€ /$ cow & $1,678^{\mathrm{a}}$ & $1,577^{\mathrm{b}}$ & $1,522^{\mathrm{c}}$ & $1,615^{\mathrm{d}}$ & $1,593^{\text {bd }}$ & 11.9 & 0.001 \\
\hline$€ /$ ha & $3,676^{\mathrm{a}}$ & $3,331^{\mathrm{b}}$ & $2,912^{\mathrm{c}}$ & $3,416^{\mathrm{b}}$ & $3,176^{\mathrm{d}}$ & 42.2 & 0.001 \\
\hline \multicolumn{8}{|c|}{ Total variable costs } \\
\hline $\mathrm{c} / \mathrm{L}$ & $10.7^{\mathrm{a}}$ & $10.7^{\mathrm{a}}$ & $10.9^{\mathrm{a}, \mathrm{b}}$ & $10.7^{\mathrm{a}}$ & $11.0^{\mathrm{b}}$ & 0.08 & 0.05 \\
\hline$€ /$ cow & $560^{\mathrm{a}}$ & $547^{\mathrm{bc}}$ & $539^{\mathrm{b}}$ & $556^{\mathrm{ac}}$ & $565^{\mathrm{a}}$ & 4.5 & 0.001 \\
\hline$€ /$ ha & $1,220^{\mathrm{a}}$ & $1,152^{\text {bd }}$ & $1,036^{\mathrm{c}}$ & $1,174^{\mathrm{d}}$ & $1,125^{\mathrm{b}}$ & 13.4 & 0.001 \\
\hline \multicolumn{8}{|l|}{ Total fixed costs } \\
\hline $\mathrm{c} / \mathrm{L}$ & $9.0^{\mathrm{a}}$ & $9.4^{\mathrm{b}}$ & $9.6^{\mathrm{b}}$ & $9.5^{\mathrm{b}}$ & $8.6^{\mathrm{c}}$ & 0.16 & 0.001 \\
\hline$€ /$ cow & $468^{\mathrm{a}}$ & $474^{\mathrm{ab}}$ & $468^{\mathrm{a}}$ & $485^{\mathrm{b}}$ & $437^{\mathrm{c}}$ & 6.4 & 0.001 \\
\hline$€ /$ ha & $1,022^{\mathrm{a}}$ & $992^{\mathrm{a}}$ & $892^{\mathrm{b}}$ & $1,019^{\mathrm{a}}$ & $858^{\mathrm{b}}$ & 15.7 & 0.001 \\
\hline \multicolumn{8}{|l|}{ Total costs } \\
\hline $\mathrm{c} / \mathrm{L}$ & $19.7^{\mathrm{a}}$ & $20.2^{\mathrm{b}}$ & $20.4^{\mathrm{b}}$ & $20.2^{\mathrm{b}}$ & $19.6^{\mathrm{a}}$ & 0.16 & 0.001 \\
\hline$€ /$ cow & $1,028^{\mathrm{ab}}$ & $1,021^{\mathrm{ac}}$ & $1,007^{\mathrm{ac}}$ & $1,042^{\mathrm{b}}$ & $1,002^{\mathrm{C}}$ & 8.5 & 0.01 \\
\hline$€ /$ ha & $2,241^{\mathrm{a}}$ & $2,144^{\mathrm{b}}$ & $1,927^{\mathrm{c}}$ & $2,193^{\mathrm{ab}}$ & $1,984^{\mathrm{c}}$ & 24.9 & 0.001 \\
\hline \multicolumn{8}{|l|}{ Net profit } \\
\hline $\mathrm{c} / \mathrm{L}$ & $12.3^{\mathrm{a}}$ & $10.9^{\mathrm{b}}$ & $10.4^{\mathrm{b}}$ & $10.9^{\mathrm{b}}$ & $11.5^{\mathrm{c}}$ & 0.19 & 0.001 \\
\hline$€ /$ cow & $650^{\mathrm{a}}$ & $556^{\mathrm{b}}$ & $515^{\mathrm{c}}$ & $574^{\text {bd }}$ & $591^{\mathrm{d}}$ & 13.8 & 0.001 \\
\hline$€ /$ ha & $1,435^{\mathrm{a}}$ & $1,187^{\mathrm{b}}$ & $985^{\mathrm{c}}$ & $1,223^{\mathrm{b}}$ & $1,192^{\mathrm{b}}$ & 28.7 & 0.001 \\
\hline
\end{tabular}

${ }^{\mathrm{a}-\mathrm{d}}$ Means with different superscripts differ significantly.

${ }^{1}$ Midlands = counties Kildare, Laois, Longford, Louth, Meath, Offaly, North Tipperary, Westmeath; Northwest = counties Cavan, Clare, Donegal, Galway, Leitrim, Mayo, Roscommon, Sligo; Southeast = counties Carlow, Kilkenny, South Tipperary, Waterford, Wexford; Southwest = counties Kerry and Limerick.

costs per liter, per cow, and per hectare were least in the Southwest region, whereas the Cork and Southeast regions had highest fixed costs per cow and per hectare. Net profit per cow and per hectare were greatest $(P<$ $0.001)$ in Cork and lowest in the Northwest region.

\section{Production System Class}

Summary statistics for biological performance parameters of farms classified on their production intensity are summarized in Table 3 . Cows in systems 1,2 , 3 , and 4 consumed 8.0, 14.9, 23.8, and $34.3 \%$ of DM from purchased feed. Although herd size was greatest for system 1 farms, stocking rate and lactation length were greater for system 3 and 4 farms. Although system 1 and 2 farms had earlier turnout dates to pasture and later rehousing dates, the total number of grazing days per hectare was lower $(P<0.05)$ than for the higher input production systems because of their lower stocking rate. Pasture harvested per hectare declined $(P<$ 0.001 ) linearly with increased use of purchased feed; for every $1 \mathrm{t}$ DM of concentrate-equivalent purchased/ ha, pasture harvested/ha declined by $0.60 \mathrm{t}$ of $\mathrm{DM} / \mathrm{ha}$ (Figure 1).

Milk yield and the yield of milk components per cow and per hectare increased linearly with increasing system intensification (Figure 2). Milk yield per cow and per hectare increased 672 and $829 \mathrm{~L} / \mathrm{t}$ DM of concentrate-equivalent purchased per cow and per hectare, respectively (i.e., all supplementary feed standardized for the ME in concentrate). Although we detected no significant difference between production systems in genetic potential for milk production (i.e., milk subindex), overall herd EBI was lower on system 4 farms, and the fertility sub-index and PTA for milk decreased and increased linearly, respectively, between system 1 and system 4 farms.

The financial performances of the different system classifications are presented in Table 4, and the withinsystem variability in net profitability per liter and per hectare are illustrated in Figure 3. Milk price and gross revenue per liter were greatest in system 1 and least in system 4. Conversely, gross revenue per cow and per hectare were greatest in system 4 and least in system 1 .

System of milk production was also associated with milk production costs and net profit. Variable milk production costs per liter, per cow, and per hectare increased linearly from system 1 to system 4; for every additional $1 \mathrm{t}$ DM of concentrate-equivalent supplementary feed/cow, variable costs increased $3.1 \mathrm{c} / \mathrm{L}$ or $€ 236 /$ cow. Additionally, although we detected no association between system class and total fixed costs per liter, total fixed costs per cow and per hectare increased with system intensification; for every additional $1 \mathrm{t}$ DM of concentrate-equivalent supplementary feed/cow, fixed costs increased $€ 63 /$ cow. On average, net profit per liter, per cow, and per hectare declined with system intensification; for every additional $1 \mathrm{t}$ 


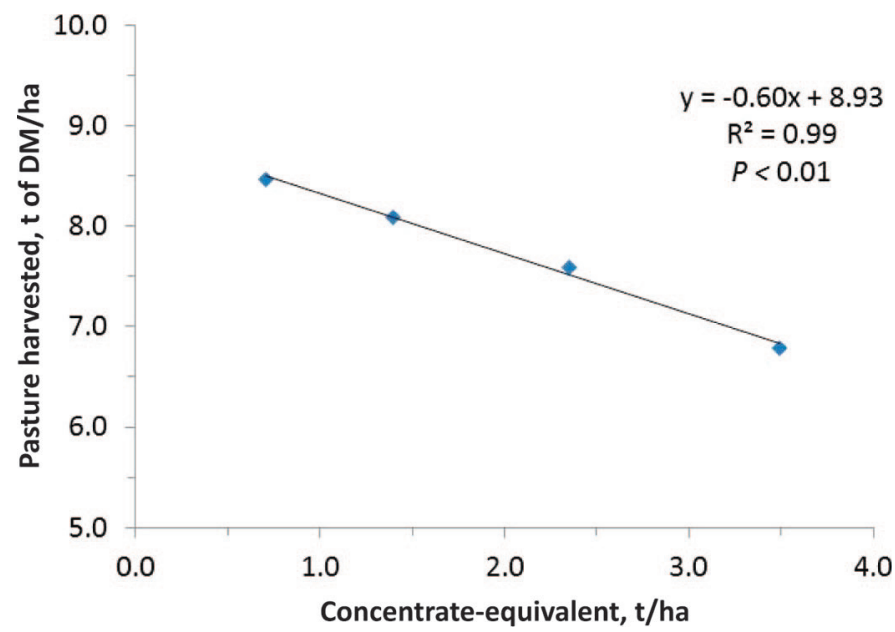

Figure 1. Relationship between increased supplementary feed imports ( $\mathrm{t} / \mathrm{ha}$ ) and pasture harvested ( $\mathrm{t}$ of $\mathrm{DM} / \mathrm{ha}$ ) on seasonal pasturebased dairy farms ( $\mathrm{n}=2,759$; years 2008 to 2011, inclusive). The data indicate a $60 \%$ substitution rate of purchased concentrate-equivalent for pasture. Color version available online.
DM of concentrate-equivalent supplementary feed/cow, net profit declined $3.7 \mathrm{c} / \mathrm{L}$ and $€ 111 /$ cow; net profit/ hectare declined by $€ 78$ for every additional $1 \mathrm{t}$ DM of concentrate-equivalent supplementary feed consumed per hectare.

The association between the extent of system intensification and individual costs are presented in Table 5. As feed costs per hectare increased, the majority of variable and fixed costs per hectare increased, although not all in a linear fashion (i.e., fertilizer, phone, bedding costs). Nonetheless, for every $€ 1 /$ ha in purchased feed costs, total cost increased $€ 1.53 /$ ha. Costs associated with liming, breeding, pasture renovation, parlor expenses, professional expenses, and land and milk quota leases were not associated with system intensification.

\section{Multiple Regression Analysis}

The farm and farming system characteristics that had the greatest association with profitability were geographical region, stocking rate, and pasture harvested

Table 3. Least squares means for measured biological characteristics in seasonal spring-calving, pasture-based dairy systems differing in farm system intensification, as measured by the percentage of DMI consumed as purchased concentrates

\begin{tabular}{|c|c|c|c|c|c|c|}
\hline \multirow[b]{2}{*}{ Item } & \multicolumn{4}{|c|}{ System $^{1}$} & \multirow[b]{2}{*}{$\mathrm{SE}$} & \multirow[b]{2}{*}{$P$-value } \\
\hline & 1 & 2 & 3 & 4 & & \\
\hline No. of farms & 430 & 1,634 & 571 & 124 & & \\
\hline \multicolumn{7}{|l|}{ Physical performance } \\
\hline Herd size, no. of cows & $96^{\mathrm{a}}$ & $83^{\mathrm{b}}$ & $82^{\mathrm{b}}$ & $84^{\mathrm{b}}$ & 2.47 & 0.001 \\
\hline Stocking rate, $\mathrm{LU}^{2} / \mathrm{ha}$ & $2.02^{\mathrm{a}}$ & $2.04^{\mathrm{a}}$ & $2.10^{\mathrm{b}}$ & $2.12^{\mathrm{b}}$ & 0.022 & 0.01 \\
\hline Median calving date, day of year & 59 & 60 & 62 & 62 & 0.7 & NS \\
\hline Full time turnout, day of year & $54^{\mathrm{a}}$ & $63^{\mathrm{b}}$ & $67^{\mathrm{c}}$ & $70^{\mathrm{c}}$ & 1.3 & 0.001 \\
\hline Housing date, days of year & $324^{\mathrm{a}}$ & $321^{\mathrm{b}}$ & $317^{\mathrm{c}}$ & $314^{\mathrm{d}}$ & 0.9 & 0.001 \\
\hline Grazing days, no./ha & $530^{\mathrm{a}}$ & $548^{\mathrm{a}}$ & $574^{\mathrm{b}}$ & $572^{\mathrm{ab}}$ & 8.3 & 0.05 \\
\hline Pasture harvested, $\mathrm{t}$ of $\mathrm{DM} / \mathrm{ha}$ & $8.5^{\mathrm{a}}$ & $8.1^{\mathrm{b}}$ & $7.6^{\mathrm{c}}$ & $6.8^{\mathrm{d}}$ & 0.09 & 0.001 \\
\hline Purchased forage, $\mathrm{t}$ of $\mathrm{DM} / \mathrm{ha}$ & $0.00^{\mathrm{a}}$ & $0.08^{\mathrm{b}}$ & $0.32^{\mathrm{c}}$ & $0.85^{\mathrm{d}}$ & 0.015 & 0.001 \\
\hline Purchased concentrate, $\mathrm{t}$ of $\mathrm{DM} / \mathrm{ha}$ & $0.71^{\mathrm{a}}$ & $1.33^{\mathrm{b}}$ & $2.07^{\mathrm{c}}$ & $2.75^{\mathrm{d}}$ & 0.019 & 0.001 \\
\hline Purchased concentrate, $\mathrm{t}$ of $\mathrm{DM} /$ cow & $0.36^{\mathrm{a}}$ & $0.66^{\mathrm{b}}$ & $0.99^{\mathrm{c}}$ & $1.31^{\mathrm{d}}$ & 0.009 & 0.001 \\
\hline Purchased feed, $\%$ of total DM & $8.0^{\mathrm{a}}$ & $14.9^{\mathrm{b}}$ & $23.8^{\mathrm{c}}$ & $34.3^{\mathrm{d}}$ & 0.11 & 0.001 \\
\hline \multicolumn{7}{|l|}{ Milk production } \\
\hline Lactation length, d (DIM) & $269^{\mathrm{a}}$ & $276^{\mathrm{b}}$ & $280^{\mathrm{c}}$ & $282^{\mathrm{c}}$ & 1.4 & 0.001 \\
\hline Milk yield, L/cow & $4,679^{\mathrm{a}}$ & $4,974^{\mathrm{b}}$ & $5,192^{\mathrm{c}}$ & $5,577^{\mathrm{d}}$ & 32.7 & 0.001 \\
\hline Milk yield, L/ha & $9,401^{\mathrm{a}}$ & $10,133^{\mathrm{b}}$ & $10,912^{\mathrm{c}}$ & $11,736^{\mathrm{d}}$ & 124.5 & 0.001 \\
\hline Fat yield, $\mathrm{kg} / \mathrm{cow}$ & $192^{\mathrm{a}}$ & $201^{\mathrm{b}}$ & $209^{\mathrm{c}}$ & $224^{\mathrm{d}}$ & 1.4 & 0.001 \\
\hline Fat yield, $\mathrm{kg} / \mathrm{ha}$ & $387^{\mathrm{a}}$ & $411^{\mathrm{b}}$ & $440^{\mathrm{c}}$ & $473^{\mathrm{d}}$ & 5.3 & 0.001 \\
\hline Protein yield, $\mathrm{kg} / \mathrm{cow}$ & $167^{\mathrm{a}}$ & $175^{\mathrm{b}}$ & $182^{\mathrm{c}}$ & $195^{\mathrm{d}}$ & 1.2 & 0.001 \\
\hline Protein yield, kg/ha & $336^{\mathrm{a}}$ & $358^{\mathrm{b}}$ & $383^{\mathrm{c}}$ & $411^{\mathrm{d}}$ & 4.5 & 0.001 \\
\hline \multicolumn{7}{|l|}{ Genetic merit } \\
\hline Herd EBI,$^{3} €$ & $81^{\mathrm{a}}$ & $76^{\mathrm{a}}$ & $73^{\mathrm{a}}$ & $66^{\mathrm{b}}$ & 0.9 & 0.001 \\
\hline Milk subindex, $€$ & 24 & 24 & 25 & 26 & 0.7 & NS \\
\hline Fertility subindex, $€$ & $50^{\mathrm{a}}$ & $45^{\mathrm{b}}$ & $41^{\mathrm{c}}$ & $34^{\mathrm{d}}$ & 0.9 & 0.001 \\
\hline PTA milk, $\mathrm{kg}$ & $33^{\mathrm{a}}$ & $49^{\mathrm{b}}$ & $63^{\mathrm{c}}$ & $87^{\mathrm{d}}$ & 2.9 & 0.001 \\
\hline
\end{tabular}

${ }^{a-d}$ Means with different superscripts differ significantly.

${ }^{1}$ Systems 1, 2, 3, and 4 refer to systems in which $<10 \%, 10-20 \%, 20-30 \%$, or $>30 \%$ of total annual feed requirements are purchased, respectively.

${ }^{2}$ Livestock units.

${ }^{3}$ Economic breeding index. 
(a)

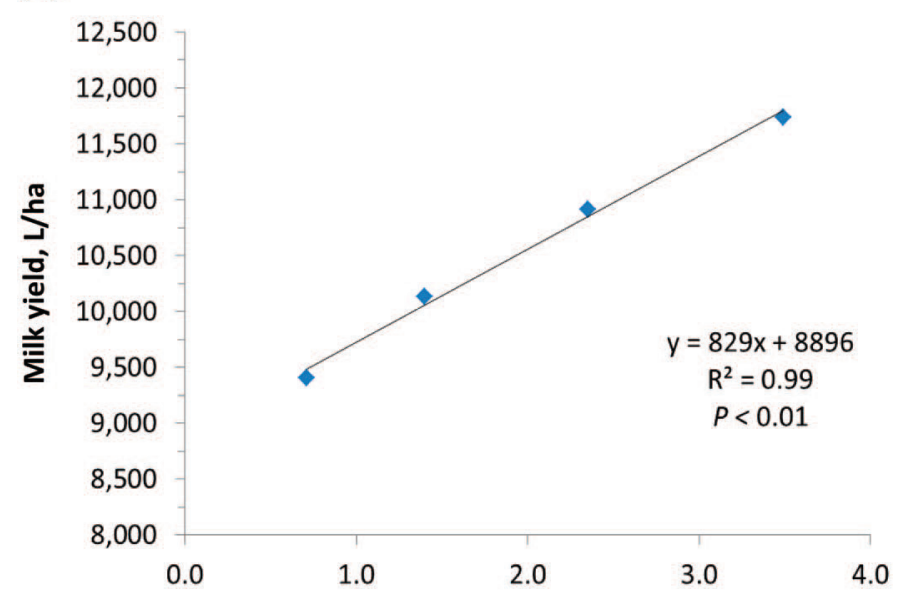

(b)

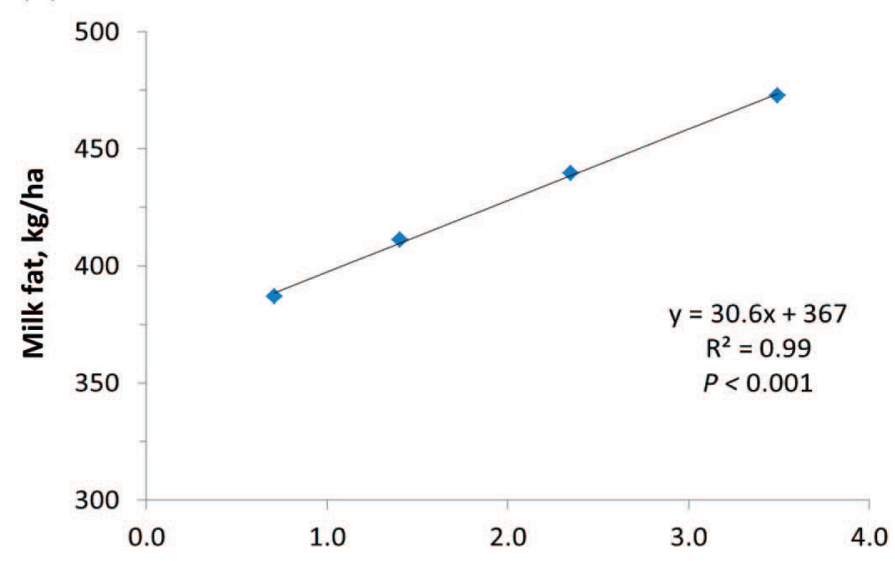

(c)

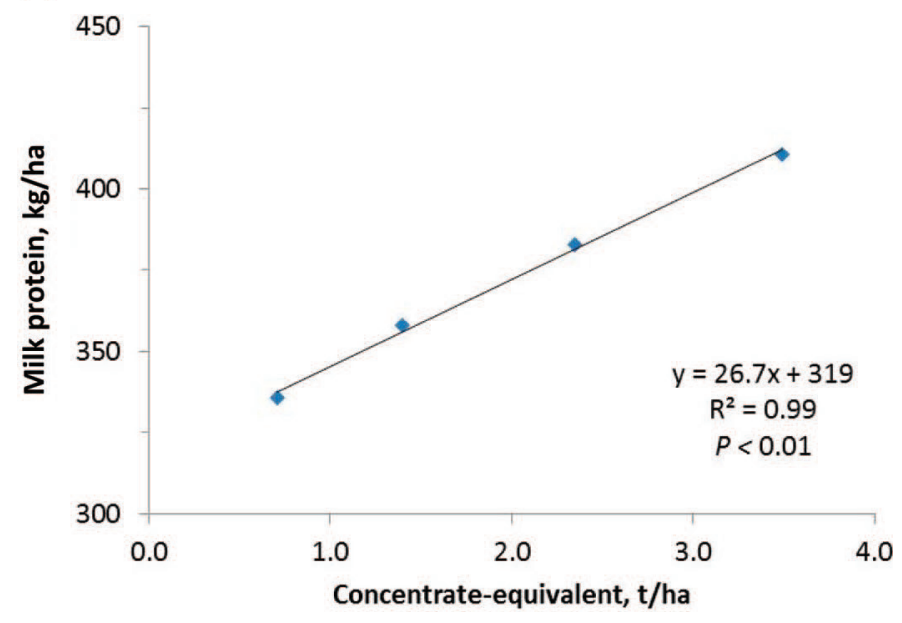

Figure 2. Association between increased supplementary feed imports (concentrate equivalent, t/ha) and milk (a), fat (b), and protein (c) production ( $\mathrm{kg} / \mathrm{ha})$ on seasonal pasture-based dairy farms $(\mathrm{n}=$ 2,759 ; years 2008 to 2011 , inclusive). Color version available online. per hectare, with yield of protein/cow and median calving date having only small, but significant, associations (Table 6). The association with median calving date differed by region, with net profit per hectare [mean (SE)] differing from Cork [€5.0 (€1.31)] to Southwest $[-€ 1.9(€ 2.03)]$. The regression analysis undertaken had $\mathrm{R}^{2}$ of $0.51,0.38$, and 0.23 for net profit per hectare, per cow, and per liter, respectively. The results highlight a decline in profitability with increasing stocking rate and lower pasture harvest per hectare.

\section{DISCUSSION}

Increasing global milk price volatility, greater frequency of detrimental climatic events (floods, droughts), increasing environmental and animal welfare regulations, and the deregulation of European Union milk quotas are likely to influence farm management decisions in the future. To remain competitive, a business must have an increased operational awareness of changing circumstances and a greater ability to adapt to such changes (Drucker, 1994; Porter, 1997). In dairying, the choice of farming system should not only represent the preferred biological method of milk production, but also, and more importantly, it must be a resilient strategy that enables the business to achieve its physical and financial objectives (Darnhofer et al., 2010). On that basis, the evaluation of farm systems must measure how adequately and effectively existing systems meet the physical and financial objectives of the business over some historical operating period, combining animal, feed input, and management practices. Although the relative financial performance of alternative farming systems has been considered using the output of research experiments (Shalloo et al., 2004; McCarthy et al., 2007), the current study provided a unique opportunity to describe how regionally diverse, seasonal, spring-calving, pasture-based systems differing in their use of purchased supplementary feeds compared on their profitability and, in so doing, identify the main factors associated with farm profitability in pasture-based systems. Overall farm profitability in the studied herds was higher than that reported previously for commercial herds in Ireland (National Farm Survey; Teagasc, 2008, 2009, 2010, 2011) during a period of relatively large variation in actual producer milk prices during the study period $(33.7 \mathrm{c} / \mathrm{L}$ in $2008,23.2 \mathrm{c} / \mathrm{L}$ in 2009, $30.8 \mathrm{c} / \mathrm{L}$ in 2010, and $35.3 \mathrm{c} / \mathrm{L}$ in 2011; CSO, 2014). The average producer milk prices and associated variability experienced during the study period are consistent with current global milk market forecasts and anticipated volatility (Teagasc, 2012) and support the robustness of the selected study period. 
Table 4. Least squares means for financial performance characteristics of seasonal spring-calving, pasturebased dairy systems differing in farm system intensification, as measured by the percentage of DMI consumed as purchased concentrates

\begin{tabular}{|c|c|c|c|c|c|c|}
\hline \multirow[b]{2}{*}{ Item } & \multicolumn{4}{|c|}{ System $^{1}$} & \multirow[b]{2}{*}{$\mathrm{SE}$} & \multirow[b]{2}{*}{$P$-value } \\
\hline & 1 & 2 & 3 & 4 & & \\
\hline Milk price, $\mathrm{c} / \mathrm{L}$ & $31.3^{\mathrm{a}}$ & $31.0^{\mathrm{b}}$ & $30.8^{\mathrm{c}}$ & $30.5^{\mathrm{c}}$ & 0.08 & 0.001 \\
\hline \multicolumn{7}{|l|}{ Gross revenue } \\
\hline $\mathrm{c} / \mathrm{L}$ & $31.6^{\mathrm{a}}$ & $31.3^{\mathrm{b}}$ & $31.1^{\mathrm{bc}}$ & $30.9^{\mathrm{c}}$ & 0.12 & 0.01 \\
\hline$€ /$ cow & $1,475^{\mathrm{a}}$ & $1,563^{\mathrm{b}}$ & $1,623^{\mathrm{c}}$ & $1,727^{\mathrm{d}}$ & 12.6 & 0.001 \\
\hline$€ /$ ha & $2,958^{\mathrm{a}}$ & $3,189^{\mathrm{b}}$ & $3,412^{\mathrm{c}}$ & $3,651^{\mathrm{d}}$ & 44.2 & 0.001 \\
\hline \multicolumn{7}{|c|}{ Total variable costs } \\
\hline $\mathrm{c} / \mathrm{L}$ & $8.7^{\mathrm{a}}$ & $10.1^{\mathrm{b}}$ & $11.5^{\mathrm{c}}$ & $12.8^{\mathrm{d}}$ & 0.09 & 0.001 \\
\hline$€ /$ cow & $405^{\mathrm{a}}$ & $499^{\mathrm{b}}$ & $595^{\mathrm{c}}$ & $715^{\mathrm{d}}$ & 4.8 & 0.001 \\
\hline$€ /$ ha & $806^{\mathrm{a}}$ & $1.012^{\mathrm{b}}$ & $1,243^{\mathrm{c}}$ & $1,504^{\mathrm{d}}$ & 14.1 & 0.001 \\
\hline \multicolumn{7}{|l|}{ Total fixed costs } \\
\hline $\mathrm{c} / \mathrm{L}$ & 9.2 & 9.2 & 9.2 & 9.2 & 0.14 & NS \\
\hline$€ /$ cow & $427^{\mathrm{a}}$ & $453^{\mathrm{b}}$ & $475^{\mathrm{c}}$ & $510^{\mathrm{d}}$ & 6.8 & 0.001 \\
\hline$€ /$ ha & $853^{\mathrm{a}}$ & $920^{\mathrm{b}}$ & $988^{\mathrm{c}}$ & $1,064^{\mathrm{d}}$ & 16.5 & 0.001 \\
\hline \multicolumn{7}{|l|}{ Total costs } \\
\hline $\mathrm{c} / \mathrm{L}$ & $18.0^{\mathrm{a}}$ & $19.2^{\mathrm{b}}$ & $20.7^{\mathrm{c}}$ & $22.1^{\mathrm{d}}$ & 0.17 & 0.001 \\
\hline$€ /$ cow & $832^{\mathrm{a}}$ & $952^{\mathrm{b}}$ & $1,070^{\mathrm{c}}$ & $1,225^{\mathrm{d}}$ & 9.0 & 0.001 \\
\hline$€ /$ ha & $1,660^{\mathrm{a}}$ & $1,932^{\mathrm{b}}$ & $2,231^{\mathrm{c}}$ & $2,568^{\mathrm{d}}$ & 26.1 & 0.001 \\
\hline \multicolumn{7}{|l|}{ Net profit } \\
\hline $\mathrm{c} / \mathrm{L}$ & $13.6^{\mathrm{a}}$ & $12.1^{\mathrm{b}}$ & $10.4^{\mathrm{c}}$ & $8.8^{\mathrm{d}}$ & 0.21 & 0.001 \\
\hline$€ /$ cow & $643^{\mathrm{a}}$ & $611^{\mathrm{b}}$ & $553^{\mathrm{c}}$ & $502^{\mathrm{d}}$ & 11.9 & 0.001 \\
\hline$€ /$ ha & $1,298^{\mathrm{a}}$ & $1,257^{\mathrm{a}}$ & $1,180^{\mathrm{b}}$ & $1,083^{\mathrm{b}}$ & 30.2 & 0.001 \\
\hline
\end{tabular}

${ }^{\mathrm{a}-\mathrm{d}}$ Means with different superscripts differ significantly.

${ }^{1}$ Systems 1, 2, 3, and 4 refer to systems in which $<10 \%, 10-20 \%, 20-30 \%$, or $>30 \%$ of total annual feed requirements are purchased, respectively.

\section{Geographical Region, Pasture Harvested per Hectare, and Profitability}

The significant regional association with farm physical and financial performance is unsurprising and has been reported previously (Shalloo et al., 2004; Läpple and Hennessy, 2012; Patton et al., 2012). This probably reflects the effect of soil type and climate on the length of the grass growth and grazing seasons and, therefore, on farm stocking rate (Dillon et al., 2008). Pasture growth and utilization are appreciably affected by soil type (Ryan, 1974) and local climatic conditions (Brereton, 1995). Shalloo et al. (2004) also reported regional differences in production costs with high rainfall, impermeable soil types, such as those found in the Northeast and Northwest regions, having 20\% greater average production costs than regions such as Cork with moderate rainfall and more free draining soils. Consequently, the same study estimated that the average farm profitability of a wetland soil type ranged from 38 to $58 \%$ of that achievable on drier soils. In this study, all measures of production and profit were greatest on dairy farms in the Cork region by virtue of a longer grazing season and increased pasture harvest per hectare; the effect of these variables on profitability is supported by the current study.

\section{Feeding Intensity and Profitability, Milk Production, and Pasture Harvested per Hectare}

Profitability of the dairy business declined, on average, with greater use of supplementary feeds, irrespective of the geographic region assessed. In general, increased costs per liter, per cow, and per hectare with increasingly intensive use of purchased supplements were not matched by increased revenue; therefore, profit declined linearly with the inclusion of purchased feeds above $10 \%$ of the cow's diet. Further examination indicates that the greater profitability in the systems purchasing less purchased supplement/cow is due to greater pasture harvest/hectare and reduced milk production costs per liter, per cow, and per hectare. The relative financial performance of alternative pasturebased farming systems has been reported previously both in Ireland, within controlled research experiments (Shalloo et al., 2004; McCarthy et al., 2007), and internationally, using commercial farm data (Kolver and Hedley, 2006; Shadbolt, 2012). These previous studies have indicated that, within a grazing system, farm management capability results in greater variability in profitability than the system of farming, as defined by intensity of feeding (Shadbolt, 2008). Although this may be true and, although there is significant within- 

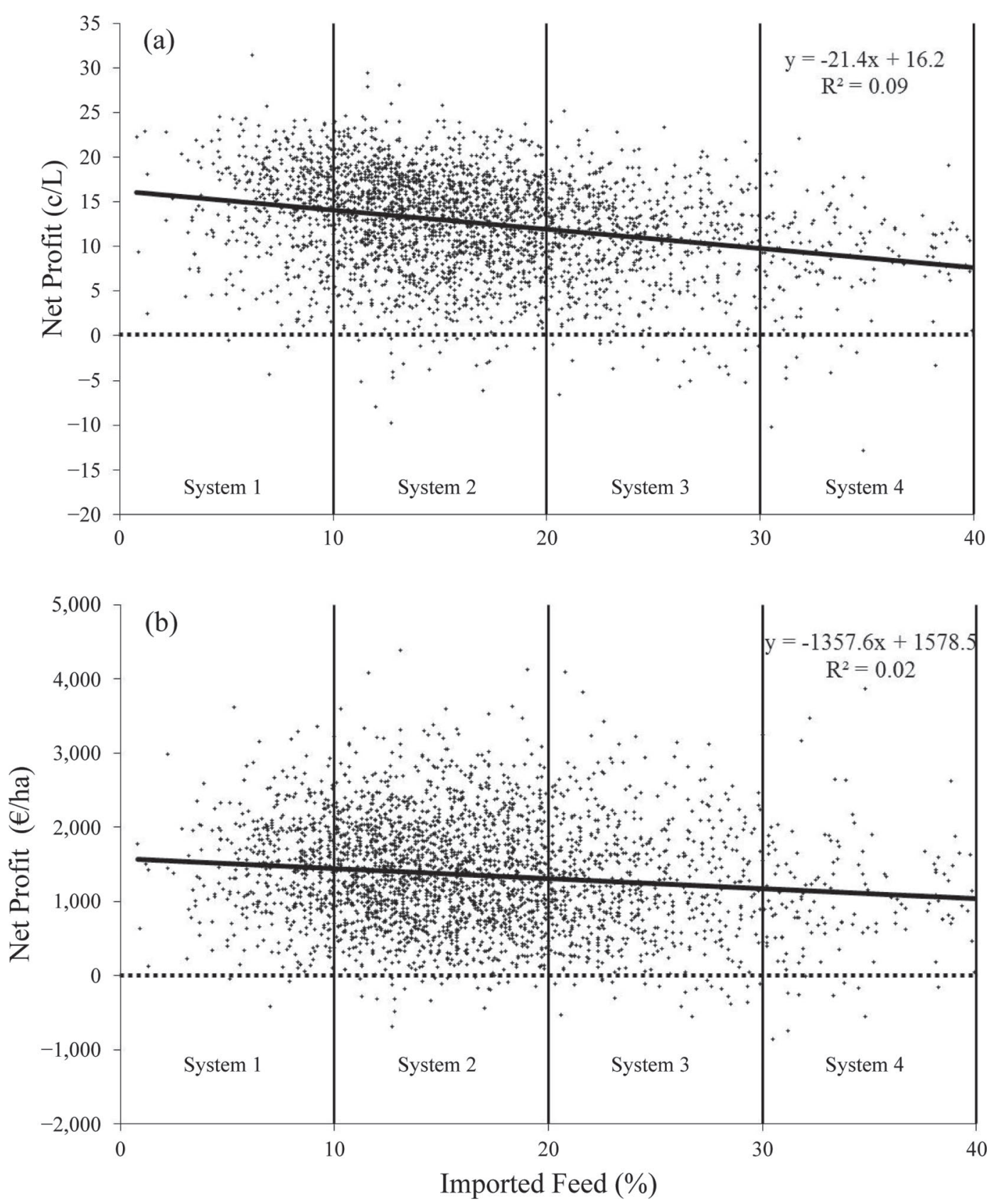

Figure 3. The association between proportion of imported feed and net profit (a) per liter and (b) per hectare on seasonal pasture-based dairy farms ( $\mathrm{n}=2,759$; years 2008 to 2011 , inclusive). Systems $1,2,3$, and 4 refer to systems in which $<10 \%, 11-20 \%, 21-30 \%$, or $>30 \%$ of total annual feed requirements are purchased, respectively.

system variability in net profitability per liter and per hectare in the current data set (Figure 3), we found significant differences in production costs, revenue, and, ultimately, profitability that could be attributed to the farming system. The results highlight that it is not the system with the greatest milk production that is the most profitable, but the system with the lowest total costs; this is true whether costs are defined as per liter, per cow, or per hectare.

Of particular note from this data set was that variable and fixed costs increased with feed use beyond the cost of the feed. On average, total costs increased by $€ 1.53$ for every $€ 1$ spent on purchased feeds. This effect is consistent with the $£ 1.62$ increase in total 
Table 5. Least squares means for variable and fixed costs of seasonal spring-calving, pasture-based dairy systems in differing farm system intensification, as measured by the percentage of DMI consumed as purchased concentrates

Cost per liter (c) Cost per cow $(€)$ Cost per hectare $(€)$

\begin{tabular}{|c|c|c|c|c|c|c|c|c|c|c|c|c|c|c|c|c|c|c|}
\hline Item & 1 & 2 & 3 & 4 & $\mathrm{SE}$ & $P$-value & 1 & 2 & 3 & 4 & $\mathrm{SE}$ & $P$-value & 1 & 2 & 3 & 4 & SE & $P$-value \\
\hline No. of farms & 430 & 1,634 & 571 & 124 & & & 430 & 1,634 & 571 & 124 & & & 430 & 1,634 & 571 & 124 & & \\
\hline $\begin{array}{l}\text { Variable costs } \\
\text { Purchased feed }\end{array}$ & $1.68^{\mathrm{a}}$ & $2.99^{\mathrm{b}}$ & $4.24^{\mathrm{c}}$ & $5.27^{\mathrm{d}}$ & 0.039 & 0.001 & $78.0^{\mathrm{a}}$ & $148.8^{\mathrm{b}}$ & $220.7^{\mathrm{c}}$ & $295.0^{\mathrm{d}}$ & 2.38 & 0.001 & $152.0^{\mathrm{a}}$ & $301.4^{\mathrm{b}}$ & $458.6^{\mathrm{c}}$ & $617.6^{\mathrm{d}}$ & 5.67 & 0.001 \\
\hline Home grown feed & 0.04 & 0.02 & 0.01 & 0.04 & 0.030 & NS & 1.9 & 1.1 & 0.7 & 2.1 & 0.54 & NS & 3.6 & 2.2 & 1.4 & 3.8 & 1.10 & NS \\
\hline Purchased forage & $0.01^{\mathrm{a}}$ & $0.12^{\mathrm{b}}$ & $0.42^{\mathrm{c}}$ & $1.03^{\mathrm{d}}$ & 0.019 & 0.001 & $0.4^{\mathrm{a}}$ & $5.8^{\mathrm{b}}$ & $21.2^{\mathrm{c}}$ & $56.7^{\mathrm{d}}$ & 0.71 & 0.001 & $0.3^{\mathrm{a}}$ & $12.5^{\mathrm{b}}$ & $47.3^{\mathrm{c}}$ & $127.2^{\mathrm{d}}$ & 2.30 & 0.001 \\
\hline Fertilizer & $2.05^{\mathrm{a}}$ & $2.05^{\mathrm{a}}$ & $2.04^{\mathrm{a}}$ & $1.83^{\mathrm{b}}$ & 0.008 & 0.01 & $95.2^{\mathrm{a}}$ & $101.3^{\mathrm{b}}$ & $104.7^{\mathrm{c}}$ & $100.8^{\mathrm{abc}}$ & 1.54 & 0.001 & $191.6^{\mathrm{a}}$ & $206.7^{\mathrm{b}}$ & $218.8^{\mathrm{c}}$ & $210.6^{\mathrm{bc}}$ & 3.83 & 0.001 \\
\hline Lime & 0.08 & 0.08 & 0.08 & 0.07 & 0.008 & NS & 3.5 & 4.1 & 4.0 & 3.9 & 0.39 & NS & 6.8 & 8.1 & 8.4 & 8.1 & 0.80 & NS \\
\hline Breeding & $0.63^{\mathrm{a}}$ & $0.59^{\mathrm{b}}$ & $0.55^{\mathrm{c}}$ & $0.51^{\mathrm{c}}$ & 0.015 & 0.001 & 29.4 & 28.9 & 28.3 & 28.2 & 0.80 & NS & 59.1 & 59.1 & 59.3 & 59.7 & 1.64 & NS \\
\hline Contractor & 1.55 & 1.51 & 1.53 & 1.46 & 0.036 & NS & $71.4^{\mathrm{a}}$ & $74.4^{\mathrm{a}}$ & $78.4^{\mathrm{b}}$ & $81.3^{\mathrm{b}}$ & 1.79 & 0.01 & $141.6^{\mathrm{a}}$ & $149.9^{\mathrm{b}}$ & $162.0^{\mathrm{c}}$ & $169.5^{\mathrm{c}}$ & 3.75 & 0.001 \\
\hline Reseeding & $0.20^{\mathrm{a}}$ & $0.18^{\mathrm{b}}$ & $0.16^{\mathrm{b}}$ & $0.18^{\mathrm{ab}}$ & 0.009 & 0.001 & 9.4 & 8.8 & 8.7 & 10.5 & 0.47 & NS & 18.7 & 17.8 & 17.9 & 21.2 & 0.95 & NS \\
\hline Parlor expenses & $0.69^{\mathrm{a}}$ & $0.65^{\mathrm{ab}}$ & $0.62^{\mathrm{bc}}$ & $0.58^{\mathrm{c}}$ & 0.019 & 0.01 & 32.2 & 32.1 & 32.2 & 32.5 & 0.97 & NS & 64.7 & 65.0 & 68.0 & 69.2 & 2.11 & NS \\
\hline Silage preservation & 0.11 & 0.12 & 0.12 & 0.12 & 0.006 & NS & $5.1^{\mathrm{a}}$ & $5.7^{\mathrm{ab}}$ & $6.3^{\mathrm{bc}}$ & $6.9^{\mathrm{c}}$ & 0.31 & 0.01 & $9.8^{\mathrm{a}}$ & $11.3^{\mathrm{b}}$ & $12.9^{\mathrm{c}}$ & $14.5^{\mathrm{c}}$ & 0.61 & 0.001 \\
\hline Levies & 0.20 & 0.22 & 0.19 & 0.21 & 0.019 & NS & 9.4 & 10.7 & 10.0 & 11.5 & 0.88 & NS & 19.0 & 21.8 & 20.7 & 24.9 & 1.94 & NS \\
\hline Bedding costs & $0.12^{\mathrm{a}}$ & $0.12^{\mathrm{a}}$ & $0.15^{\mathrm{b}}$ & $0.12^{\mathrm{a}}$ & 0.008 & 0.001 & $5.4^{\mathrm{a}}$ & $6.0^{\text {ac }}$ & $7.9^{\mathrm{b}}$ & $6.9^{\mathrm{bc}}$ & 0.38 & 0.001 & $11.1^{\mathrm{a}}$ & $12.4^{\text {ac }}$ & $16.9^{\mathrm{bc}}$ & $14.7^{\mathrm{c}}$ & 0.84 & 0.001 \\
\hline Other variable costs & 0.33 & 0.35 & 0.32 & 0.37 & 0.017 & NS & $15.1^{\mathrm{a}}$ & $17.2^{\mathrm{b}}$ & $16.3^{\mathrm{ab}}$ & $20.7^{\mathrm{c}}$ & 0.86 & 0.01 & $30.5^{\mathrm{a}}$ & $35.1^{\mathrm{b}}$ & $34.6^{\mathrm{ab}}$ & $41.6^{\mathrm{c}}$ & 1.82 & 0.001 \\
\hline Fixed costs & & & & & & & & & & & & & & & & & & \\
\hline Hired labor & $0.95^{\mathrm{a}}$ & $0.78^{\mathrm{b}}$ & $0.70^{\mathrm{b}}$ & $0.79^{\mathrm{ab}}$ & 0.062 & 0.05 & 43.0 & 38.6 & 36.2 & 43.3 & 3.05 & NS & 92.3 & 83.5 & 79.2 & 91.7 & 7.05 & NS \\
\hline Machinery running & 1.09 & 1.15 & 1.20 & 1.19 & 0.036 & NS & $50.2^{\mathrm{a}}$ & $57.0^{\mathrm{b}}$ & $61.4^{\mathrm{c}}$ & $65.4^{\mathrm{c}}$ & 1.82 & 0.001 & $98.7^{\mathrm{a}}$ & $115.1^{\mathrm{b}}$ & $126.4^{\mathrm{c}}$ & $136.5^{\mathrm{c}}$ & 3.86 & 0.001 \\
\hline Machinery leases & 0.25 & 0.27 & 0.29 & 0.30 & 0.036 & NS & 12.0 & 13.6 & 15.2 & 17.0 & 1.81 & NS & 24.8 & 27.3 & 30.6 & 32.5 & 3.75 & NS \\
\hline Short-term credit interest & $0.11^{\mathrm{a}}$ & $0.12^{\mathrm{a}}$ & $0.15^{\mathrm{b}}$ & $0.13^{\mathrm{ab}}$ & 0.013 & 0.05 & $5.0^{\mathrm{a}}$ & $5.7^{\mathrm{a}}$ & $7.8^{\mathrm{b}}$ & $7.5^{\mathrm{ab}}$ & 0.68 & 0.01 & $9.9^{\mathrm{a}}$ & $11.8^{\mathrm{ab}}$ & $16.0^{\mathrm{b}}$ & $16.6^{\mathrm{b}}$ & 1.47 & 0.05 \\
\hline Long-term loan interest & 0.72 & 0.70 & 0.72 & 0.76 & 0.047 & NS & 33.0 & 34.4 & 37.4 & 42.2 & 2.32 & NS & $67.5^{\mathrm{a}}$ & $70.8^{\mathrm{a}}$ & $78.4^{\mathrm{ab}}$ & $92.6^{\mathrm{b}}$ & 5.07 & 0.001 \\
\hline Car running & 0.53 & 0.54 & 0.56 & 0.52 & 0.019 & NS & $24.6^{\mathrm{a}}$ & $26.8^{\mathrm{b}}$ & $28.4^{\mathrm{b}}$ & $28.2^{\mathrm{b}}$ & 0.94 & 0.05 & $47.3^{\mathrm{a}}$ & $53.4^{\mathrm{b}}$ & $57.6^{\mathrm{b}}$ & $58.2^{\mathrm{b}}$ & 1.90 & 0.001 \\
\hline Power & $0.56^{\mathrm{a}}$ & $0.58^{\mathrm{b}}$ & $0.62^{\mathrm{c}}$ & $0.63^{\mathrm{c}}$ & 0.012 & 0.001 & $25.7^{\mathrm{a}}$ & $28.8^{\mathrm{b}}$ & $31.8^{\mathrm{c}}$ & $34.8^{\mathrm{d}}$ & 0.59 & 0.001 & $51.1^{\mathrm{a}}$ & $58.4^{\mathrm{b}}$ & $65.6^{\mathrm{c}}$ & $73.4^{\mathrm{d}}$ & 1.34 & 0.001 \\
\hline Phone & 0.18 & 0.19 & 0.19 & 0.18 & 0.006 & NS & $8.6^{\mathrm{a}}$ & $9.2^{\mathrm{ac}}$ & $9.9^{\mathrm{bc}}$ & $10.1^{\mathrm{c}}$ & 0.31 & 0.01 & $16.9^{\mathrm{a}}$ & $18.4^{\mathrm{b}}$ & $20.1^{\mathrm{c}}$ & $20.8^{\mathrm{c}}$ & 0.62 & 0.001 \\
\hline Building depreciation & 0.96 & 0.98 & 1.03 & 1.07 & 0.037 & NS & $44.8^{\mathrm{a}}$ & $48.8^{\mathrm{b}}$ & $53.3^{\mathrm{c}}$ & $59.9^{\mathrm{c}}$ & 1.88 & 0.001 & $89.3^{\mathrm{a}}$ & $98.7^{\mathrm{b}}$ & $111.6^{\mathrm{c}}$ & $125.0^{\mathrm{c}}$ & 4.03 & 0.001 \\
\hline Machinery depreciation & 1.00 & 1.02 & 0.95 & 0.88 & 0.036 & NS & 46.7 & 50.7 & 49.0 & 48.6 & 1.85 & NS & $91.9^{\mathrm{a}}$ & $102.8^{\mathrm{b}}$ & $102.8^{\mathrm{b}}$ & $101.8^{\mathrm{ab}}$ & 3.98 & 0.01 \\
\hline Repairs and maintenance & 0.70 & 0.74 & 0.77 & 0.77 & 0.034 & NS & $32.3^{\mathrm{a}}$ & $36.8^{\mathrm{b}}$ & $39.7^{\mathrm{b}}$ & $42.4^{\mathrm{b}}$ & 1.70 & 0.01 & $63.2^{\mathrm{a}}$ & $73.9^{\mathrm{b}}$ & $82.6^{\mathrm{c}}$ & $86.7^{\mathrm{c}}$ & 3.53 & 0.001 \\
\hline Insurance fees & 0.47 & 0.46 & 0.45 & 0.48 & 0.014 & NS & $21.8^{\mathrm{a}}$ & $22.9^{\mathrm{a}}$ & $23.2^{\mathrm{a}}$ & $26.3^{\mathrm{b}}$ & 0.64 & 0.01 & $42.9^{\mathrm{a}}$ & $46.1^{\mathrm{b}}$ & $48.2^{\mathrm{b}}$ & $54.7^{\mathrm{c}}$ & 1.32 & 0.001 \\
\hline Professional fees & $0.51^{\mathrm{a}}$ & $0.48^{\mathrm{ab}}$ & $0.47^{\mathrm{b}}$ & $0.43^{\mathrm{b}}$ & 0.014 & 0.05 & 23.5 & 23.9 & 22.9 & 23.7 & 0.69 & NS & 46.7 & 47.8 & 49.6 & 48.5 & 1.43 & NS \\
\hline Sundry fixed & 0.29 & 0.29 & 0.28 & 0.33 & 0.018 & NS & 13.5 & 14.2 & 14.4 & 18.2 & 0.91 & NS & $26.1^{\mathrm{a}}$ & $28.6^{\mathrm{a}}$ & $29.3^{\mathrm{a}}$ & $37.5^{\mathrm{b}}$ & 1.69 & 0.05 \\
\hline Land lease & 0.84 & 0.79 & 0.78 & 0.69 & 0.044 & NS & 38.9 & 38.8 & 40.2 & 38.7 & 2.16 & NS & 77.1 & 76.9 & 83.3 & 80.9 & 4.41 & NS \\
\hline Quota lease & 0.07 & 0.06 & 0.06 & 0.07 & 0.015 & NS & 3.5 & 2.9 & 3.2 & 3.9 & 0.73 & NS & 7.1 & 6.2 & 7.0 & 7.1 & 1.87 & NS \\
\hline
\end{tabular}

${ }^{\mathrm{a}-\mathrm{d}}$ Means with different superscripts differ significantly.

${ }^{1}$ Systems $1,2,3$, and 4 refer to systems in which $<10,10-20,20-30$, or $>30 \%$ of total annual feed requirements are purchased, respectively. 
Table 6. Significant $(P<0.05)$ linear factors (SE in parentheses) used to model net profit per hectare, per cow, and per liter ( $\mathrm{n}=2,742$; years 2008 to 2011 , inclusive)

\begin{tabular}{lcrr}
\hline & \multicolumn{3}{c}{ Net profit } \\
\cline { 2 - 4 } Item & \multicolumn{1}{c}{$€ /$ ha } & $€ /$ cow & \multicolumn{1}{c}{$\mathrm{c} / \mathrm{L}$} \\
\hline Mean square prediction error & 0.51 & 0.38 & 0.23 \\
Intercept & $-1,802.2(164.08)$ & $-228.5(77.58)$ & $6.98(1.570)$ \\
Region & & & \\
Cork & $-423.6(151.08)$ & $-214.9(71.43)$ & $-4.46(1.445)$ \\
Midlands & $-280.5(164.05)$ & $-132.9(77.56)$ & $-2.65(1.569)$ \\
Northwest & $35.8(183.21)$ & $37.0(86.62)$ & $1.00(1.753)$ \\
Southeast & $-395.2(154.38)$ & $-209.7(72.99)$ & $-4.20(1.476)$ \\
Southwest & $0(-)$ & $0(-)$ & $0(-)$ \\
Stocking rate, LU ${ }^{2} /$ ha & $-449.6(58.65)$ & $-506.5(27.72)$ & $-10.47(0.561)$ \\
Yield, kg of protein/cow & $9.2(0.46)$ & $4.5(0.22)$ & $0.02(0.004)$ \\
Pasture harvested, t of DM/ha & $323.7(14.36)$ & $150.6(6.79)$ & $3.13(0.138)$ \\
Median calving date, day of year & & & \\
Cork & $5.0(1.31)$ & $2.4(0.62)$ & $0.05(0.013)$ \\
Midlands & $1.7(1.58)$ & $0.6(0.75)$ & $0.01(0.015)$ \\
Northwest & $-1.8(1.86)$ & $-1.4(0.88)$ & $-0.03(0.017)$ \\
Southeast & $2.6(1.48)$ & $1.5(0.700)$ & $0.03(0.014)$ \\
Southwest & $-1.9(2.03)$ & $-1.2(0.96)$ & $-0.03(0.019)$ \\
\hline
\end{tabular}

${ }^{1}$ Midlands = counties Kildare, Laois, Longford, Louth, Meath, Offaly, North Tipperary, Westmeath; Northwest = counties Cavan, Clare, Donegal, Galway, Leitrim, Mayo, Roscommon, Sligo; Southeast = counties Carlow, Kilkenny, South Tipperary, Waterford, Wexford; Southwest = counties Kerry and Limerick.

${ }^{2}$ Livestock units.

costs for every $£ 1$ spent on nonforage feed costs in the UK national data set (AHDB, 2013). The increase identified in the presented data set was not attributable to any one variable or fixed cost, with the majority of costs rising in conjunction with feed costs. Some of these increases are plausibly related to costs associated with feeding purchased supplements (i.e., hidden costs: machinery running costs, power, repairs and maintenance), although some increases are difficult to associate with system intensification (e.g., fertilizer) and, so, likely reflect the farmer's overall attitude to cost control. Although associative in nature, the relationships between purchased feed expenses and other variable and fixed costs are important in determining the likely profitability of a marginal adjustment in feed use on commercial dairy farms and highlight complications in the use of marginal analyses calculations (e.g., margin over feed) on business profitability, at least in pasturebased systems when fixed and variable costs intertwine.

The increase in milk production/hectare that can be attributed to the purchased supplement is lower than previously published responses. Milk production/cow in this study increased by $0.67 \mathrm{~L} / \mathrm{kg}$ of $\mathrm{DM}$ concentrateequivalent purchased. By comparison, in their comprehensive reviews of the subject, both Stockdale (2000) and Bargo et al. (2003) reported an average marginal milk production response to concentrate supplementation of $1 \mathrm{~L}$ of milk $/ \mathrm{kg}$ of DM concentrate consumed. More recent experiments capturing the immediate and deferred milk production response to concentrate supplements put the response at 1.1 to $1.3 \mathrm{~L} / \mathrm{kg}$ of DM concentrate (Kennedy et al., 2002; Horan et al., 2005; Roche et al., 2013), with the greater response relative to previous reports probably a result of genetic selection for milk production at the expense of energy being partitioned to BW gain (Roche et al., 2006; McCarthy et al., 2007). In the present data set, the increase in purchased supplement also facilitated an increase in stocking rate; if this is accounted for, the marginal milk production response to purchased supplement is 0.83 $\mathrm{L}$ of milk/ $\mathrm{kg}$ of DM concentrate-equivalent purchased. The on-farm milk production response to purchased supplements is, therefore, $20 \%$ less than average responses from comprehensive reviews (Stockdale, 2000; Bargo et al., 2003) and approximately 30\% less than reported in more recent research experiments. The identified decline in profitability with supplement use is, therefore, due in part to a low biological response to the purchased feed.

The most notable effect of increasing the proportion of the cow's diet from purchased supplementary feed was the substantial reduction in pasture harvested/ hectare. For every $1 \mathrm{t}$ of DM concentrate-equivalent purchased/cow, pasture consumption/cow declined by $0.77 \mathrm{t}$ of DM. However, as stocking rate also increased with increased feed use, the substitution rate of supplement for pasture was less than this $(0.6 \mathrm{t}$ of $\mathrm{DM} /$ ha). The relationship between concentrate-equivalent purchased/hectare and pasture harvested/hectare presented in Figure 1 represents an average substitu- 
tion rate of $60 \%$ over the season. A decline in pasture eaten/cow when a supplement is consumed is to be expected (Stockdale, 2000; Bargo et al., 2003; Sheahan et al., 2011). Neuroendocrine factors are secreted from various tissues to inform the brain of the energy status of the cow (Roche et al., 2008). When cows consume a supplement, satiety signals cause the cows to graze for less time (12 min $/ \mathrm{kg}$ of DM concentrate consumed; Bargo et al., 2003; Sheahan et al., 2011) and consume fewer bites/min (i.e., a lower bite rate; Sheahan et al., 2013).

Nevertheless, the estimated substitution rate in the present study is high relative to that reported in the literature for well-managed grazing systems (Stockdale, 2000; Linnane et al., 2004; Sheahan et al., 2011). The factor that most influences substitution rate is pasture allowance/cow (Stockdale, 2000; Bargo et al., 2003), with substitution rate increasing as pasture allowance/ cow increases. As pasture utilization declines with pasture allowance (Wales et al., 1998; Ganche et al., 2014), the effect of purchased feed on pasture harvest/ hectare would appear to be a failure on the part of the dairy farmer to properly adjust pasture allowance to account for the supplementary feed offered. Substitution rate and the marginal milk production response to supplementary feed are closely related (Stockdale, 2000; Bargo et al., 2003), with the marginal milk production response declining $0.08 \mathrm{~L}$ for every $10 \%$ increase in substitution rate (Stockdale, 2000). The decline in profitability with increasing use of purchased feeds is consistent with recent studies that have highlighted the important contribution of grazed pasture to net farm profit/hectare (Dillon et al., 2008; Shalloo, 2009). If pasture harvested/hectare had not declined with increasing use of purchased feeds, milk production/ hectare could conceivably have been greater by 0.25 $\mathrm{L} / \mathrm{kg}$ of DM purchased feed, which would have been in line with marginal responses reported from research experiments. This would have resulted in an increase in revenue with no additional increase in variable or fixed costs and, provided milk and feed were appropriately priced, would have resulted in a positive return to the dairy farmer's investment in purchased supplement.

\section{Feeding Intensity and Business Resilience}

Resilience in a business is the ability to manage or adapt to change and is a key factor in financial sustainability in a volatile commodity market. Although in a TMR-based system, resilience can be viewed as the ability of a business to reduce costs by more than revenue in a low milk price environment or to increase production through improved nutrition by more than the increase in costs in a high milk price environment, business resilience is simpler in grazing systems. Financial success in grazing systems is defined by pasture utilization, which, in turn, is positively affected by pasture grown and stocking rate (cows/ha) and negatively affected by the amount of feed purchased. These parameters are strategically defined for individual businesses to optimize pasture utilization. Consequently, a grazing system is less able than a TMR-based system to take advantage of a milk price upswing by increased expenditure on supplementary feeds, because such an action would reduce pasture utilized. Therefore, we are defining business resilience for our purposes as the ability to withstand a decrease in milk price.

If resilience in a grazing system is, therefore, defined by the cost of production, the results presented here reflect an increase in the vulnerability of the average farm business with increasing use of purchased feeds. Although there is significant variability in farm profitability in all systems (Figure 3), on average the total cost of production increases linearly with the proportion of feed consumed originating from purchased feeds (total costs were $56,61,65$, and $70 \%$ of gross output/ hectare for systems $1,2,3$, and 4 , respectively). This change is likely to undermine the resilience of these businesses in a milk production environment characterized by volatile milk prices. Despite its importance, farm business resilience has seldom been considered directly in evaluations of economic sustainability. The results presented here illustrate the considerable effects of intensifying the dairy system through greater use of purchased feed to increase stocking rate on both return and risk within the dairy farm business.

\section{CONCLUSIONS}

Ultimately, the optimum production system is that which results in the greatest profit per unit of the most limiting input, which, in most grazing systems, is land. Profitability per hectare is, therefore, considered the most important financial criterion within this analysis. The regression analysis undertaken in this study highlights the important contribution of stocking rate, median calving date, yields of fat and protein per cow, and pasture harvested/hectare to overall farm profitability per liter, per cow, and per hectare across all production systems and geographical regions. Similar to previous studies, the results presented here indicate that pasture-based systems with limited supplementary feed inputs deliver the greatest profits and, by virtue of their lower production costs, insulate the farm business from milk and feed price volatility. The decline in pasture harvested/hectare with increased use of purchased 
supplements/cow is likely the primary reason for the low milk production response and the failure to capitalize on the potential benefits of purchased supplements, with the associated costs of growing the unutilized pasture in conjunction with increased nonfeed variable and fixed costs outweighing the increased milk production and revenue from supplementation. Farmers considering intensification through use of purchased supplements to increase the stock-carrying capacity of the farm (i.e., stocking rate) must ensure that they focus on their management of pasture and total cost control to capture the potential benefits of supplementary feed use.

\section{REFERENCES}

AHDB. 2013. Milkbench+, Profiting from efficient milk production. Agriculture and Horticulture Development Board (AHDB), Stoneleigh Park, Kenilworth, UK.

Bargo, F., L. D. Muller, E. S. Kolver, and J. E. Delahoy. 2003. Invited review: Production and digestion of supplemented dairy cows on pasture. J. Dairy Sci. 86:1-42.

Berry, D. P., L. Shalloo, A. R. Cromie, R. F. Veerkamp, P. Dillon, P. R. Amer, J. F. Kearney, R. D. Evans, and B. Wickham. 2007. The economic breeding index: A generation on. Technical report to the Irish Cattle Breeding Federation. Accessed June 19, 2009. http:// www.icbf.com/publications/files/economic_breeding_index.pdf.

Brereton, A. J. 1995. Regional and year-to-year variation in production. Pages 12-22 in Irish Grasslands: Their Biology and Management. D. W. Jeffery, M. B. Jones, and J. H. McAdam, ed. Royal Irish Academy, Dublin, Ireland.

Central Statistics Office. 2014. Manufacturing milk price (including VAT) by product and year. Accessed June 6, 2014. http://www.cso.ie/px/pxirestat/Statire/SelectVarVal/Define. asp? maintable=AJM06.

Darnhofer, I., S. Bellon, B. Dedieu, and R. Milestad. 2010. Adaptiveness to enhance the sustainability of farming systems: A review. Agron. Sustain. Dev. 30:545-555. http://dx.doi.org/10.1051/ agro/2009053.

Dillon, P., S. Crosse, G. Stakelum, and F. Flynn. 1995. The effect of calving date and stocking rate on the performance of springcalving dairy cows. Grass Forage Sci. 50:286-299.

Dillon, P., T. Hennessy, L. Shalloo, F. Thorne, and B. Horan. 2008. Future outlook for the Irish dairy industry: A study of international competitiveness, influence of international trade reform and requirement for change. Int. J. Dairy Technol. 61:16-29.

Dillon, P., L. Shalloo, M. Wallace, and A. M. Butler. 2005. Integrated modeling of dairy production systems under technical, environmental and economic scenarios. Final Report Project No. 5062, Teagasc, Oak Park, Carlow, Ireland.

Drucker, P. 1994. The Theory of the Business. Harvard Bus. Rev. SepOct. https://hbr.org/1994/09/the-theory-of-the-business.

Ganche, E., L. Delaby, M. O'Donovan, T. M. Boland, and E. Kennedy. 2014. Short-term response in milk production, dry matter intake and grazing behavior of dairy cows to changes in postgrazing sward height. J. Dairy Sci. 97:3028-3041.

Hedley, P., E. Kolver, C. Glassey, B. Thorrold, A. van Bysterveldt, J. R. Roche, and K. Macdonald. 2006. Achieving high performance from a range of farm systems. Pages 147-166 in Proc. 4th Dairy3 Conf. 4. Massey University, Palmerston North, New Zealand.

Holmes, C. 2007. What are the key issues for profitable dairy production? Pages 3-22. Proc. 5th Dairy3 Conf. Rotorua, New Zealand. I. M. Brookes, ed. Massey University, Palmerston North, New Zealand.

Horan, B., P. Dillon, P. Faverdin, L. Delaby, F. Buckley, and M. Rath. 2005. The interaction of strain of Holstein Friesian cows and pas- ture based feed systems on milk yield, body weight and body condition score. J. Dairy Sci. 88:1231-1243.

Horan, B., J. F. Mee, M. Rath, P. O'Connor, and P. Dillon. 2004. The effect of strain on Holstein-Friesian cow and feed system on reproductive performance in seasonal-calving milk production systems. Anim. Sci. 79:453-469.

Kennedy, J., P. Dillon, P. Faverdin, L. Delaby, F. Buckley, and M. Rath. 2002. The influence of cow genetic merit for milk production on response to level of concentrate supplementation in a grassbased system. Anim. Sci. 75:433-445.

Kolver, E. S., and P. A. Hedley. 2006. Achieving high performance from a range of farm systems in the South Island. Pages 141-167 in Proc. South Island Dairy Event 6, New Zealand. Lincoln University, Canterbury, New Zealand.

Kolver, E. S., and L. D. Muller. 1998. Performance and nutrient intake of high-producing Holstein cows consuming pasture or a total mixed ration. J. Dairy Sci. 81:1403-1411.

Läpple, D., and T. Hennessy. 2012. The capacity to expand milk production in Ireland following the removal of milk quotas. Ir. J. Agric. Food Res. 51:1-11.

Linnane, M., B. Horan, J. Connelly, P. O'Connor, F. Buckley, and P. Dillon. 2004. The effect of strain of Holstein-Friesian and feeding system on grazing behaviour, herbage intake and productivity in the first lactation. Anim. Sci. 78:169-178.

Macdonald, K. A., D. Beca, J. W. Penno, J. A. S. Lancaster, and J. R. Roche. 2011. Short communication: Effect of stocking rate on economics of pasture-based dairy farms. J. Dairy Sci. 94:2581-2586.

Macdonald, K. A., and J. W. Penno. 1998. Management decision rules to optimise milksolids production on dairy farms. Proc. N.Z. Soc. Anim. Prod. 58:132-135.

Macdonald, K. A., J. W. Penno, J. A. S. Lancaster, and J. R. Roche. 2008. Effect of stocking rate on pasture production, milk production and reproduction of dairy cows in pasture-based systems. J. Dairy Sci. 91:2151-2163.

McCarthy, B., L. Delaby, K. M. Pierce, F. Journot, and B. Horan. 2011. Meta-analysis of the impact of stocking rate on the productivity of pasture-based milk production systems. Animal 5:784794

McCarthy, S., B. Horan, P. Dillon, P. O'Connor, M. Rath, and L. Shalloo. 2007. Economic comparison of divergent strains of Holstein-Friesian cows in various pasture-based production systems. J. Dairy Sci. 90:1493-1505.

Met Eireann. 2014. Climate-30-year averages. Met Eireann, Ireland. Accessed May 19, 2014. http://www.met.ie/climateireland/30year-averages.asp.

Patton, D., L. Shalloo, K. M. Pierce, and B. Horan. 2012. A biological and economic comparison of 2 pasture-based production systems on a wetland drumlin soil in the northern region of Ireland. J. Dairy Sci. 95:484-495.

Porter, M. E. 1997. Creating tomorrow's advantages. Pages 49-61 in Rethinking The Future. R. Gibron, ed. Nicholas Brealey Publishing, London, UK.

Ramsbottom, G., A. R. Cromie, B. Horan, and D. P. Berry. 2012. Relationship between dairy cow genetic merit and profit in commercial Irish spring-calving dairy farms. Animal 6:1031-1039.

Roche, J. R., D. P. Berry, and E. S. Kolver. 2006. Holstein-Friesian strain and feed effects on milk production, body weight and body condition score profiles in grazing dairy cows. J. Dairy Sci. 89:3532-3543.

Roche, J. R., D. Blache, J. Kay, D. Miller, A. Sheahan, and D. Miller. 2008. Neuroendocrine and physiological regulation of intake, with particular reference to domesticated ruminant animals. Nutr. Res. Rev. 21:207-234.

Roche, J. R., J. K. Kay, A. G. Rius, T. M. Grala, A. J. Sheahan, H. M. White, and C. V. C. Phyn. 2013. Short communication: Immediate and deferred milk production responses to concentrate supplements in cows grazing fresh pasture. J. Dairy Sci. 96:2544-2550.

Roche, J. R., L. R. Turner, J. M. Lee, D. C. Edmeades, D. J. Donaghy, K. A. Macdonald, J. W. Penno, and D. P. Berry. 2009. Weather herbage quality and milk production in pastoral systems. 2. Tem- 
poral patterns and intra-relationships in herbage quality and mineral concentration parameters. Anim. Prod. Sci. 49:200-210.

Ryan, M. 1974. Grassland productivity: 1. Nitrogen and soil effects on yield of herbage. Isr. J. Agric. Res. 13:275-291.

SAS Institute. 2005. SAS/STAT User's Guide. SAS Institute Inc., Cary, NC.

Shadbolt, N. M. 2008. Strategic management of farm businesses: The role of strategy tools with particular reference to the balanced scorecard. J. Farm Manag. 13:205-218.

Shadbolt, N. M. 2012. Competitive strategy analysis of NZ pastoral dairy farming systems. Int. J. Agric. Manag. 1:19-27.

Shalloo, L. 2009. Pushing the barriers on milk costs/outputs. Pages 19-39 in National Dairy Conference, Mullingar \& Killarney. Teagasc, Carlow, Ireland.

Shalloo, L., P. Dillon, J. O'Loughlin, M. Rath, and M. Wallace. 2004. Comparison of a pasture based system of milk production on a high rainfall, heavy clay soil with that on a lower rainfall, free draining soil. Grass Forage Sci. 59:157-168.

Sheahan, A. J., E. S. Kolver, and J. R. Roche. 2011. Genetic strain and diet effects on grazing behavior, pasture intake, and milk production. J. Dairy Sci. 94:3583-3591.
Sheahan, A. J., S. J. Gibbs, and J. R. Roche. 2013. Timing of supplementation alters grazing behavior and milk production responses in dairy cows. J. Dairy Sci. 96:477-483.

Stockdale, C. R. 2000. Levels of pasture substitution when concentrates are fed to 234 grazing dairy cows in Northern Victoria. Aust. J. Exp. Agric. 40:913-921.

Teagasc. 2008. National Farm Survey 2008. Teagasc, Carlow, Ireland. Teagasc. 2009. National Farm Survey 2009. Teagasc, Carlow, Ireland. Teagasc. 2010. National Farm Survey 2010. Teagasc, Carlow, Ireland.

Teagasc. 2011. National Farm Survey 2011. Teagasc, Carlow, Ireland.

Teagasc. 2012. Your road maps to better farming 2020: Dairy. Teagasc Carlow, Ireland. Accessed May 18, 2014. http://www.teagasc.ie/ publications/2013/2890/DairyRoadMap2020.pdf.

Wales, W. J., P. T. Doyle, and D. W. Dellow. 1998. Dry matter intake and nutrient selection by lactating cows grazing irrigated pastures at different pasture allowances in summer and autumn. Aust. J. Exp. Agric. 38:451-460. 